\title{
Negative effect of the arthropod parasite, Sarcoptes scabiei, on testes mass in Iberian ibex, Capra pyrenaica
}

\author{
Mathieu Sarasa ${ }^{\mathrm{a}, \mathrm{b}, *}$, Emmanuel Serrano $^{\mathrm{c}}$, Ramón C. Soriguer ${ }^{\mathrm{d}}$, José-Enrique Granados ${ }^{\mathrm{e}}$, \\ Paulino Fandos ${ }^{\mathrm{f}}$, Georges Gonzalez ${ }^{\mathrm{b}}$, Jean Joachim ${ }^{\mathrm{b}}$, Jesús M. Pérez ${ }^{\mathrm{a}}$ \\ a Departamento de Biología Animal, Biología Vegetal y Ecología, Facultad de Ciencias Experimentales, Universidad de Jaén, E-23071 Jaén, Spain \\ b Laboratoire Comportement et Ecologie de la Faune Sauvage, Institut National de la Recherche Agronomique, BP 52627, F-31326 Castanet-Tolosan, France \\ c Servei dǐEcopatologia de Fauna Salvatge, Facultat de Veterinària, Universitat Autònoma de Barcelona, E-08193 Bellaterra, Spain \\ d Estación Biológica de Doñana, E-41092 Sevilla, Spain \\ e Espacio Natural Sierra Nevada, E-18071 Pinos Genil, Granada, Spain \\ ${ }^{f}$ EGMASA, Isla de la Cartuja, E-41092 Sevilla, Spain
}

Keywords:

Capra pyrenaica

Parasitic castration

Sarcoptes scabiei

Sarcoptic mange

Testis

Ungulate

\begin{abstract}
a b s t $r$ a c t
Testes mass is a key factor in male reproductive success and is potentially exposed to so-called 'parasitic castration'. This is the result of the direct destruction or alteration of reproductive cell lineages (parasitic castration sensu stricto), or the indirect detrimental effects - for example, via body condition - on the ability of progenitors to produce or rear offspring (parasitic castration sensu lato). There are enormous gaps in our knowledge on the effects of parasites on the testes of wild mammals and in an attempt to rectify this dearth of data we examined the relationship between the skin parasite Sarcoptes scabiei and testes mass in Iberian ibex Capra pyrenaica. We considered data from 222 males that were culled in the population from the Sierra Nevada in Spain. Our results provide evidence that sarcoptic mange is associated with reduced size-corrected testes mass in Iberian ibex which supports the hypothesis that parasitism is a determining factor in gonad plasticity in male mammals. We discuss several hypothetical causes of this relationship and highlight the need to deepen the sub-lethal effects of pathogens if we are to accurately understand their modulator effects on host population dynamics.
\end{abstract}

\section{Introduction}

Testes size is a key factor in male reproductive success (Preston et al., 2003; Schulte-Hostedde and Millar, 2004) given that big testes are an advantageous trait in species with sperm competition (Preston et al., 2003; Schärer et al., 2004; Schärer and Vizoso, 2007). Primary sexual characters vary with mating tactics (Harcourt et al., 1981; Awata et al., 2006), body condition (Schulte-Hostedde and Millar, 2004; Schulte-Hostedde et al., 2005a) and season, at least in

* Corresponding author. Present address: 10, place des Oustalots, F64400 Oloron-Sainte-Marie, France. Tel.: +34660126149.

E-mail address: mathieusar@hotmail.com (M. Sarasa). seasonal breeders (Goeritz et al., 2003). Gonads, however, are also potentially exposed to so-called 'parasitic castration' (Baudoin, 1975). This can result in the direct alteration or even destruction of reproductive organs (parasitic castration sensu stricto) and can be temporary or definitive (Baudoin, 1975; Ruiz-Martínez et al., 1993). 'Parasitic castration' can also refer to indirect detrimental effects - for example, via body condition - on the ability of progenitors to produce or rear offsprings (parasitic castration sensu lato) (Barnard and Behnke, 1990; Hudson and Dobson, 1997; Møller, 1997).

The direct effects of parasites on gonads have mostly been recorded to date in invertebrate taxa (Baudoin, 1975). In vertebrates most studies that have reported reduced mating and rearing capacity in parasitized hosts have been 

performed on birds (Hurtrez-Boussès et al., 1998; Bize et al., 2004; Marzal et al., 2005; Velando et al., 2006) and fish (Pélabon et al., 2005; Kolluru et al., 2009). What little data concerning wild mammals that exists generally deals with female fecundity (Iason and Boag, 1988; Pence and Windberg, 1994; Neuhaus, 2003; Newey and Thirgood, 2004; Newey et al., 2004; Pioz et al., 2008) or host behavior (Cramer and Cameron, 2007) and there are enormous gaps in our knowledge regarding the effects of parasites on the testes of wild mammals. Recently, Santiago-Moreno et al. (2010) examined the relationship between sperm quality and the level of parasitism in Iberian ibex. Nevertheless, all animals examined in their study were selectively hunted for their relatively small horn development and individual phenotypic quality was not considered in their analysis as a potential confounding factor. Also, despite some determining factors of testis traits have nonlinear effects and despite testis traits are governed simultaneously by multiple factors (Sarasa et al., 2010b), the most highlighted analysis in the study of Santiago-Moreno et al. (2010) looked separately for linear relationships. Moreover, only one from the six sperm variables considered showed a weak relationship with one from the five parasitic classes considered (Santiago-Moreno et al., 2010). Consequently, like in almost all wild-living mammal species, the relationship between parasites and testes traits has to be deepened in Iberian ibex.

In this work, we examined the relationship between sarcoptic mange caused by Sarcoptes scabiei and testes mass in Iberian Ibex Capra pyrenaica. This endemic ungulate from the Iberian Peninsula has suffered in recent decades severe epizootic episodes of sarcoptic mange, which have become one of the most important destabilizing factors operating on the population dynamics of the Iberian ibex (Pérez et al., 2002). Sarcoptic mange is widespread in wild mammals and it is known to induce marked increases in mortality rates (Pence and Ueckermann, 2002). However, the sublethal effects of sarcoptic mange and, more particularly, its effects on reproductive success in wild fauna, are still under-considered.

According to the parasitic castration hypothesis (Baudoin, 1975; Lafferty and Kuris, 2009) or to the adaptive plasticity of parasitized hosts (Forbes, 1993; Perrin et al., 1996; Hurd, 2001), we would expect mange to have a negative effect on testes, to be expressed as a decrease in relative testes mass in mangy as opposed to uninfected individuals.

Clinical testicular alterations were recorded in individuals with severe sarcoptic mange infestation in some species (Little et al., 1998; Skerratt et al., 1999; Soulsbury et al., 2007). Despite the lack of consensus on the subject, negative effects of chorioptic mange (Chorioptes bovis) on testicular activity in domestic rams were reported (Rhodes, 1975, 1976; Heath, 1978). These studies highlight the need to go into this topic in 'mange-wild host' interactions.

\section{Materials and methods}

\subsection{Study site and population}

We studied the Iberian ibex population of the Sierra Nevada $\left(36^{\circ} 00^{t}-37^{\circ} 10^{t} \mathrm{~N}, 2^{\circ} 34^{t}-3^{\circ} 40^{t} \mathrm{~W}\right.$, Spain) that is a reference population in long term monitoring and experimental approaches in Iberian ibex ecology (Pérez et al., 1994; Sarasa et al., 2009; Serrano et al., in press). In particular, numerous studies were focused on the interaction between sarcoptic mange and Iberian ibex (Pérez et al., 1997, 2006; Serrano et al., 2007; Alasaad et al., 2008; Sarasa et al., 2010a). In this study we considered three categories of mange infestation: 0 = mange-free males; 1 = moderate lesions that include cases with lesions in $<50 \%$ of host skin surface and the initial and development stages described by León-Vizcaíno et al. (1999); 2 = severe lesions that include cases with lesions in more than $50 \%$ of host skin surface and the consolidation and chronic stages as per León-Vizcaíno et al. (1999). We considered data from 222 males (Table 1), which were culled by the Natural Space staff for management purposes in the periods 1995-1998, 2000-2003, 2007 and 2008. At culling, each individual was weighed to the nearest $500 \mathrm{~g}$ and measured to the nearest $0.5 \mathrm{~cm}$; age was assessed by horn-segment counts (Fandos, 1991). At necropsy, the animals' testicles were removed and weighed to the nearest $0.01 \mathrm{~g}$. The arithmetic mean of the mass of the two testicles was used as the initial testicle mass.

\subsection{Analysis}

To examine the relative effect of explanatory variables we estimated several residuals (detailed below) (Sarasa et al., 2010b) and in each case we chose the best fitted regression between linear and non-linear models based on the Akaike's Information Criterion, AIC (Burnham and Anderson, 2002). We log-transformed body mass and testes mass to normalize the data. Shoulder height is one of the highest growth priorities during juvenile skeletal development in Iberian ibex (Fandos, 1991) and so to control for allometry on testes mass we used the residuals of the linear regression of the log-transformed arithmetic mean of the mass of both testes on shoulder height. This

Table 1

Distribution of sampled animals.

\begin{tabular}{|c|c|c|c|c|c|c|c|c|c|c|c|c|c|}
\hline \multicolumn{14}{|c|}{ (a) Distribution of sampled animals per months } \\
\hline Month & 1 & 2 & 3 & 4 & 5 & 6 & 7 & 8 & 9 & 10 & 11 & 12 & Total \\
\hline Sample size & 11 & 22 & 26 & 33 & 10 & 28 & 6 & 16 & 18 & 32 & 17 & 3 & 222 \\
\hline \multicolumn{14}{|c|}{ (b) Distribution of samples animals per age (in years) } \\
\hline Age & 1 & 2 & 3 & 4 & 5 & 6 & 7 & 8 & 9 & 10 & 13 & & Total \\
\hline Sample size & 15 & 46 & 69 & 39 & 19 & 12 & 7 & 7 & 3 & 4 & 1 & & 222 \\
\hline \multicolumn{14}{|c|}{ (c) Distribution of sampled animals per mange categories } \\
\hline Mange category & & \multicolumn{4}{|c|}{ Mange-free (0) } & \multicolumn{4}{|c|}{ Moderate mange (1) } & \multicolumn{3}{|c|}{ Severe mange (2) } & Total \\
\hline Sample size & & & 175 & & & & 19 & & & & 28 & & 222 \\
\hline
\end{tabular}


Table 2

Model selection on determining factors of size-corrected testis mass.

\begin{tabular}{|c|c|c|c|c|c|c|c|c|c|}
\hline Model & $\mathrm{n}$ & K & AICc & 6AICc & $\mathrm{L}(\mathrm{gi} / \mathrm{x})$ & $\mathrm{Wi}$ & R-sq(adj) & RI & \\
\hline $\mathrm{M}+\mathrm{S}+\mathrm{A}+\mathrm{BC}+\mathrm{S} * \mathrm{~A}+\mathrm{M} * \mathrm{~S}+\mathrm{M} * \mathrm{BC}$ & 222 & 13 & -50.49 & 0.00 & 1.00 & 0.21 & 0.763 & M: & 1.00 \\
\hline $\mathrm{M}+\mathrm{S}+\mathrm{A}+\mathrm{BC}+\mathrm{S} * \mathrm{~A}+\mathrm{M} * \mathrm{~S}$ & 222 & 12 & -49.97 & 0.52 & 0.77 & 0.17 & 0.763 & $\mathrm{M} * \mathrm{~S}:$ & 0.88 \\
\hline $\mathrm{M}+\mathrm{S}+\mathrm{A}+\mathrm{BC}+\mathrm{S} * \mathrm{BC}+\mathrm{M} * \mathrm{~S}+\mathrm{M} * \mathrm{BC}$ & 222 & 13 & -49.94 & 0.54 & 0.76 & 0.16 & 0.756 & $\mathrm{M} * \mathrm{BC}:$ & 0.56 \\
\hline $\mathrm{M}+\mathrm{S}+\mathrm{A}+\mathrm{BC}+\mathrm{S} * \mathrm{BC}+\mathrm{M} * \mathrm{~S}$ & 222 & 12 & -49.37 & 1.11 & 0.57 & 0.12 & 0.762 & $\mathrm{M} * \mathrm{~A}:$ & 0.25 \\
\hline $\mathrm{M}+\mathrm{S}+\mathrm{A}+\mathrm{BC}+\mathrm{S} * \mathrm{~A}+\mathrm{M} * \mathrm{~S}+\mathrm{M} * \mathrm{~A}+\mathrm{M} * \mathrm{BC}$ & 222 & 14 & -48.21 & 2.27 & 0.32 & 0.07 & 0.762 & & \\
\hline $\mathrm{M}+\mathrm{S}+\mathrm{A}+\mathrm{BC}+\mathrm{S} * \mathrm{~A}+\mathrm{M} * \mathrm{~S}+\mathrm{M} * \mathrm{~A}$ & 222 & 13 & -47.75 & 2.74 & 0.25 & 0.05 & 0.763 & & \\
\hline $\mathrm{M}+\mathrm{S}+\mathrm{A}+\mathrm{BC}+\mathrm{S} * \mathrm{BC}+\mathrm{M} * \mathrm{~S}+\mathrm{M} * \mathrm{~A}+\mathrm{M} * \mathrm{BC}$ & 222 & 14 & -47.67 & 2.82 & 0.24 & 0.05 & 0.755 & & \\
\hline $\mathrm{M}+\mathrm{S}+\mathrm{A}+\mathrm{BC}+\mathrm{S} * \mathrm{BC}+\mathrm{M} * \mathrm{~S}+\mathrm{M} * \mathrm{~A}$ & 222 & 13 & -47.32 & 3.17 & 0.21 & 0.04 & 0.757 & & \\
\hline $\mathrm{M}+\mathrm{S}+\mathrm{A}+\mathrm{BC}+\mathrm{S} * \mathrm{~A}+\mathrm{M} * \mathrm{BC}$ & 222 & 12 & -46.71 & 3.77 & 0.15 & 0.03 & 0.766 & & \\
\hline $\mathrm{M}+\mathrm{S}+\mathrm{A}+\mathrm{BC}+\mathrm{S} * \mathrm{~A}$ & 222 & 11 & -46.21 & 4.28 & 0.12 & 0.03 & 0.764 & & \\
\hline $\mathrm{M}+\mathrm{S}+\mathrm{A}+\mathrm{BC}+\mathrm{S} * \mathrm{BC}$ & 222 & 11 & -45.13 & 5.35 & 0.07 & 0.01 & 0.765 & & \\
\hline $\mathrm{M}+\mathrm{S}+\mathrm{A}+\mathrm{BC}+\mathrm{S} * \mathrm{BC}+\mathrm{M} * \mathrm{BC}$ & 222 & 12 & -44.90 & 5.59 & 0.06 & 0.01 & 0.762 & & \\
\hline $\mathrm{M}+\mathrm{S}+\mathrm{A}+\mathrm{BC}+\mathrm{S} * \mathrm{~A}+\mathrm{M} * \mathrm{~A}+\mathrm{M} * \mathrm{BC}$ & 222 & 13 & -44.53 & 5.96 & 0.05 & 0.01 & 0.764 & & \\
\hline $\mathrm{M}+\mathrm{S}+\mathrm{A}+\mathrm{BC}+\mathrm{S} * \mathrm{~A}+\mathrm{M} * \mathrm{~A}$ & 222 & 12 & -43.99 & 6.50 & 0.04 & 0.01 & 0.762 & & \\
\hline $\mathrm{M}+\mathrm{S}+\mathrm{A}+\mathrm{BC}+\mathrm{S} * \mathrm{BC}+\mathrm{M} * \mathrm{~A}$ & 222 & 12 & -42.97 & 7.52 & 0.02 & 0.00 & 0.764 & & \\
\hline $\mathrm{M}+\mathrm{S}+\mathrm{A}+\mathrm{BC}+\mathrm{S} * \mathrm{BC}+\mathrm{M} * \mathrm{~A}+\mathrm{M} * \mathrm{BC}$ & 222 & 13 & -42.66 & 7.83 & 0.02 & 0.00 & 0.761 & & \\
\hline $\mathrm{S}+\mathrm{A}+\mathrm{BC}+\mathrm{S} * \mathrm{~A}$ & 222 & 10 & -39.79 & 10.70 & 0.00 & 0.00 & 0.758 & & \\
\hline $\mathrm{S}+\mathrm{A}+\mathrm{BC}+\mathrm{S} * \mathrm{BC}$ & 222 & 10 & -37.92 & 12.57 & 0.00 & 0.00 & 0.754 & & \\
\hline
\end{tabular}

M, Mange; S, Season; A, Age; BC, Body Condition; *, interaction, MO, null model; K, number of estimated parameters; AICc, Information Criterion corrected for small sample size; 6AICc, difference of AICc between the model and the most parsimonious model; L(gi/x), Probability of the model being the best model given the data set; Wi, Akaike weight of the model; R-sq(adj), adjusted $\mathrm{R}^{2}$ of the fitted model; RI, Relative Importance of factors (Burnham and Anderson, 2002; Wood, 2006).

size-corrected testes mass (corrected for allometry) was used as the dependent variable in our analysis.

To avoid non-independence of body condition from other explanatory factors, we used body condition corrected for season, age and mange as a body-condition index in our analyses. To account for seasonality in body condition we calculated the residuals of the linear regression of log-transformed body mass on shoulder height (SchulteHostedde et al., 2005b) fitted separately for each season. Just for this correction, we defined seasons in agreement with local phenology as follows: winter from 15 December to 5 March, spring from 6 March to 15 June, summer from 16 June to 15 September and autumn from 16 September to 14 December (Consejería de Medio Ambiente - Junta de Andalucía, 2002). Next, we used the residuals of the logistic regression of seasonal-specific body condition on age to control for the effect of age on body condition (Garthwaite et al., 1986; Harper, 1998; Kyle et al., 2001; Hughes et al., 2002). Finally, we used the residuals of the linear regression of body condition (previously corrected for season and age) on the degree of mange infestation ( $0=$ mange-free; 1 = moderate lesions; 2 = severe lesions) to control for the effect of mange on body condition (Pence and Windberg, 1994; Skerratt, 2003; Davidson et al., 2008).

Taking into account the effects of age, body condition, and season, we used generalized additive mixed models, GAMM (Wood, 2006; Zuur et al., 2007), with year as the random factor and an information-theoretic approach (Whittingham et al., 2006) based on Akaike's Information Criterion corrected for small sample size, AICc (Burnham and Anderson, 2002), to test for the effects of sarcoptic mange on allocation to testes mass (Sarasa et al., 2010b). Our aim was to examined the relationship between sarcoptic mange and testes mass in comparison with the determining factors of allocation to testes mass reported for uninfected individuals (Sarasa et al., 2010b). Thus, we compared the best models explaining testes mass variability in mange-free ibexes (Sarasa et al., 2010b) with models to which the mange factor was added, with and without its two-order interactions with other factors (identifying the most parsimonious model: lowest AICc). The relative importance (RI) of explanatory variables was also examined (Anderson et al., 2000, 2001; Burnham and Anderson, 2002).

All analyses were performed using the R 2.9.0 statistical package (R Development Core Team, 2009).

\section{Results}

We found that sarcoptic mange infestation is negatively linked to relative testes mass in Iberian ibex, particularly during the rutting season (autumn), and even at moderate degree of infestation. Four models appeared to have substantial support (6AICc lower to two units, see Table 2) given the data set (Burnham and Anderson, 2002). Those models are refined versions (including the mange factor) of the two best models that reported the determining factors of allocation to testes mass in mange-free individuals (Sarasa et al., 2010b). The mange factor and its interactions with season was included in all four best models (Table 2), which highlights the clear negative effect of mange on size-corrected testes mass and the fact that this relationship was more patent in than outside the rutting season (Fig. 1). Moreover, two of the four models with substantial support (including the best one) included the interaction between mange infestation and body condition. As shown in Fig. 2, the condition-dependent allocation to size-corrected testes mass may be modulated by the degree of mange infestation. Furthermore, of the tested models, those that did not take into account the mange factor were the worst ranked, which highlights the importance of the parasitic status of hosts in explaining the observed variability of testes mass.

The results are consolidated by the multi-model inference. The relative importance (RI) of the mange factor was equal to one, which underlines the strength of its role as 


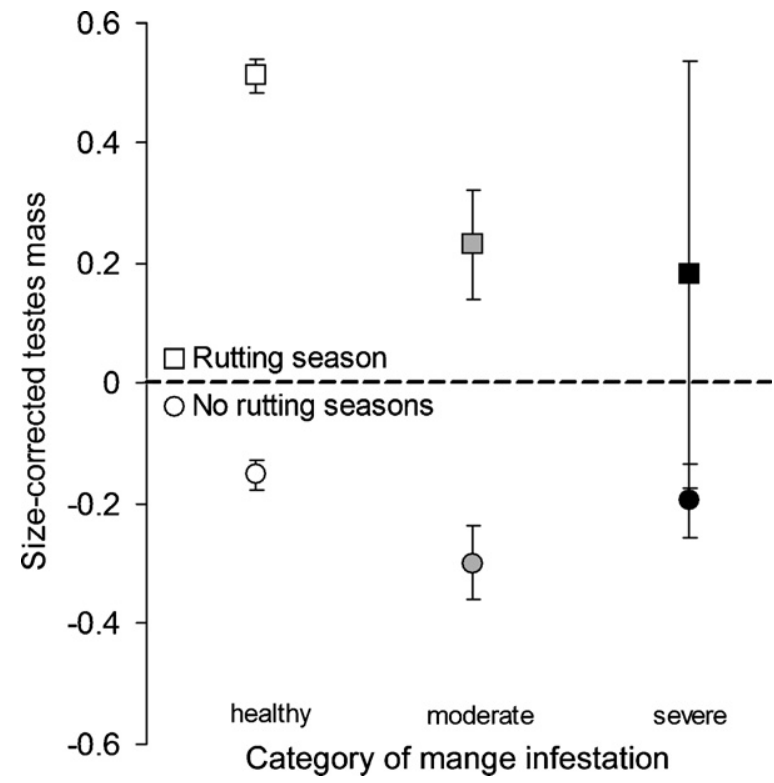

Fig. 1. Effect of sarcoptic mange on size-corrected testes mass in Iberian ibex Capra pyrenaica (Sierra Nevada, Spain) in rutting (autumn) and nonrutting seasons (other seasons). Points correspond to the mean values and error bars represent the standard error. Note that 'season' was a continuous variable in the fitted models (coded as 12 months) and was only divided into rutting and non-rutting seasons for the figure. Mange was included in model as continuous variable and categories have been made only for the figure as well.

a major determining factor of allocation to testes mass (Table 2). The RI of interactions between sarcoptic mange and the other factors agrees with the pattern inferred from the ranking of the best models. The RI of the interaction with season was the highest, followed by the RI interaction with body condition and age (Table 2). Finally, estimates of the adjusted $\mathrm{R}^{2}$ of the fitted models were high (Table 2 ), which underlines that the considered factors explained a great proportion of the variability in testes mass (more than 75\%). This argues that in our analyses we considered the main determining factors of testes size. Thus, no major confounding factor is expected.

\section{Discussion}

As per our prediction, our results present evidence that sarcoptic mange is associated with reduced testes mass in Iberian ibex. To our knowledge, this is the first study providing strong evidence of a negative relationship, even at moderate degree of infestation, between an arthropod skin parasite, which do not necessarily affect the scrotal area, and testes mass in a wild mammal.

\subsection{Adaptive allocation or parasitic castration?}

As per our prediction, sarcoptic mange appeared to negatively influence size-corrected testes mass, although this relationship seems to be to some extent modulated by the effects of season. This pattern can be interpreted in two ways: these results may be due to the adaptive reduction of allocation to testes (and thus of reproductive
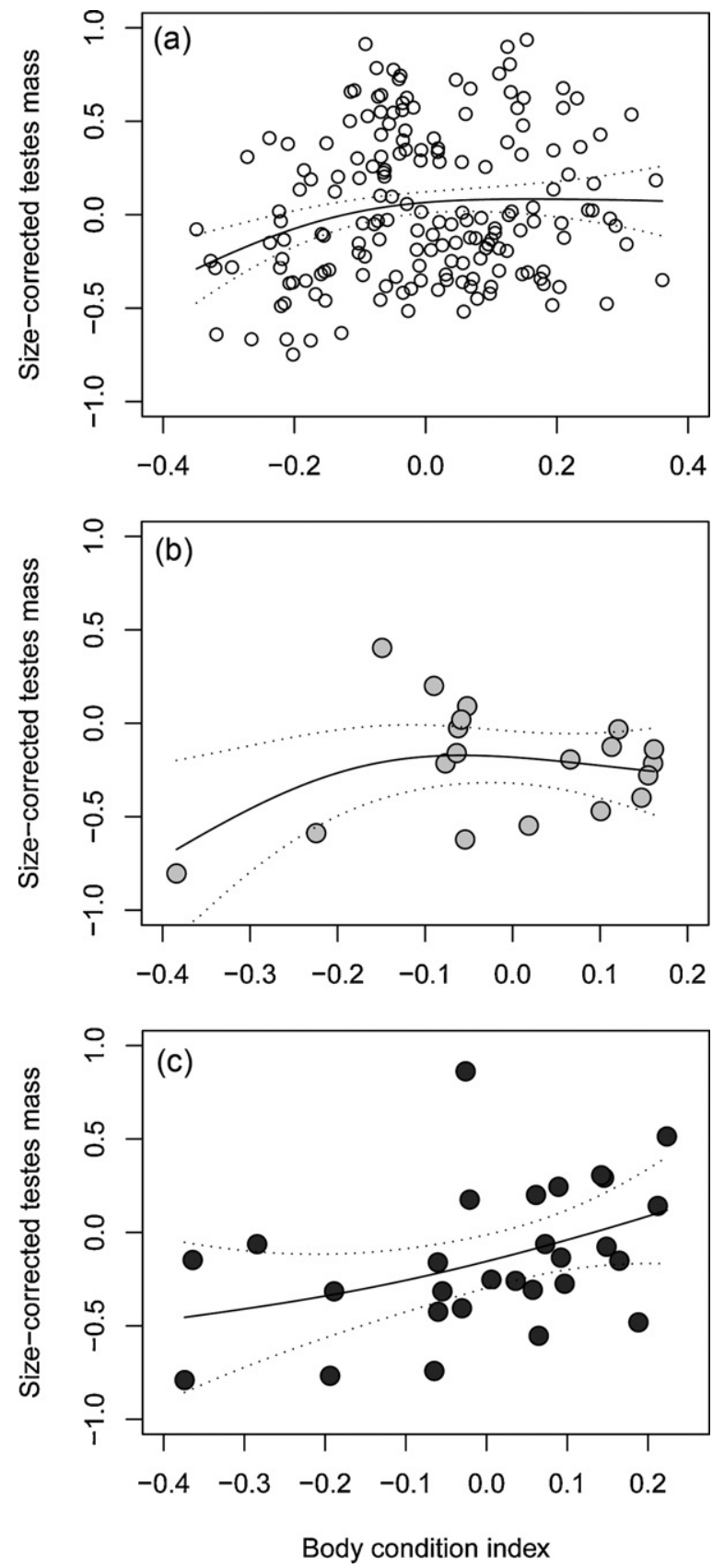

Fig. 2. Effect of body condition on size-corrected testes mass in Iberian ibex Capra pyrenaica (Sierra Nevada, Spain) in (a) mange-free ibexes, (b) ibexes with moderate mange and (c) ibexes with severe mange. The solid line represents the estimated pattern and dotted lines indicate 95\% confidence intervals (Bowman and Azzalini, 1997). Mange was included in model as continuous variable and categories have been made only for the figure.

effort) in mangy individuals (Forbes, 1993; Perrin et al., 1996) or a direct consequence of the impact of parasitism on host physiology and gonads (Baudoin, 1975). Recent studies provided direct and indirect evidences that mange modulates numerous physiological processes of the host, such as antioxidant (Dimri et al., 2008; Camkerten et al., 
2009) and immunological defenses (Kuhn et al., 2008; Elder et al., 2009; Fischer et al., 2009; Sarasa et al., 2010a). The identification of the engaged molecules is still an ongoing process. Physiological measurements, though, will be required if we are to discriminate between the hypothesis of host adaptive allocation and the hypothesis of direct parasitic impact on host gonads (Møller, 1997). A search for Sarcoptes-derived modulators of testicular plasticity or an examination of host regulatory hormones of testicular activity in mangy individuals might allow us to advance a step further towards a resolution of this question.

Under the hypothesis of the adaptive reduction of reproductive effort (Forbes, 1993; Perrin et al., 1996), the reallocation of energy from reproduction to confronting a pathogenic challenge might be expected to improve host recovery and survival probabilities. Under the parasitic castration hypothesis (Baudoin, 1975) we would expect relative optimization of life expectancy in infested hosts and hijacking of energy allocated to host reproduction by parasite (Obrebski, 1975). This final feature is of special selective advantage in contact-transmitted pathogens as opposed to parasites transmitted in the food chain (Moore and Gotelli, 1990). Consequently, given that Sarcoptes is a contact-transmitted pathogen able to modulate host physiology (Sarasa et al., 2010a), no mechanism can yet be excluded.

Moreover, the need to study the complexity of the observed pattern is highlighted again by the mangemodulated trend between body condition and allocation to testes mass, and by the great variability in the allocation to testes mass during the rutting season in individuals with severe mange infection. It is difficult to provide a single rigorous interpretation of the effect of the interaction between mange and body condition on allocation to testes mass and of the great variability of testes mass in individual with severe lesions. Considering that mange induces multidimensional alterations in host phenotype and that allocation to testes mass is regulated simultaneously by multiple factors, further investigation into the succession of phenotypic damage linked to the development of mange (Arlian et al., 1990; Pence and Ueckermann, 2002; Nakagawa et al., 2009) and into the hypothesis associated with terminal investment in ill individuals (Velando et al., 2006) might throw further light on these subjects.

It is worth pointing out also that mange infestations are associated in some host species to different co-infections and parasitic communities (Balestrieri et al., 2006). Thus, the possible additive role of other pathogens will have to be assessed too.

In all instances, our results suggest that the lesions observed by other authors in the testes of some individuals with severe mange infestations (Little et al., 1998; Skerratt et al., 1999; Soulsbury et al., 2007) are possibly a common phenomenon which affects mangy individuals at all levels of parasitism (see Fig. 1).

\subsection{On the expectable 'role' of infested hosts}

Parasitism is known to affect the social behavior of hosts in host-pathogen systems (Hart, 1988; O’Donnell, 1997; Hughes et al., 2004). Testis size is intimately associated to testosterone dynamics (Lincoln, 1998; Toledano-Díaz et al., 2007), and testosterone is predictive of a male's rank trajectory (Beehner et al., 2006), of likeliness to initiate aggressions (Virgin and Sapolsky, 1997) and of outcome of male-male interactions (Bergman et al., 2006). Thus, through testosterone, a relationship between testes size and behavior is highly plausible. In light of the reduced testes mass in mangy individuals, it would be reasonable to expect the competitiveness of infested individuals to be negatively affected in agonistic behavior, and for there to be an increase in the frequency of undergone agonistic behavior, such as is observed after other types of destabilizing stimuli (Pelletier et al., 2004). Thus, mange infestations possibly induce ultimately a destabilization of social ranking. Consequently, reduced testes mass in mangy individual may not only threaten reproductive success through sperm competition (Coltman et al., 2002; Preston et al., 2003), but may also severely hinder the recruitment, the courtship and eventually the mating success of infested hosts. As a result, alterations in the effective population size and structure might be expected to occur (Wright, 1931, 1938). A reduction of the effective population size (as global effect) and a terminal investment effect just in some individual categories (with severe lesions, as suggested in the next to last paragraph of Section 4.1) are both theoretically plausible. The terminal investment strategy (increased reproductive investment) usually concerns categories of individuals with poor reproductive prospects, and categories with greater reproductive prospects can adaptively reduce reproductive investment (Møller, 1997; Velando et al., 2006). These subjects will have to be further studied in order to refine predictions regarding the dynamics of parasitized populations (Gulland, 1995) and to broaden our knowledge of the host-Sarcoptes arms race (Combes, 1995).

Moreover, if the reduced allocation to testes mass correlates with the forementioned social alterations, as it would be reasonable to expect, then mangy individuals would be of even more interest in pathogen transmission dynamics. Sarcoptes might opportunistically take advantage of attacks to declining ibexes and to disperse horizontally among the group and the population, like other pathogens seem to do (Miller and Williams, 2003). Thus, our results may enrich epidemiological models (McCallum et al., 2001), given that they reveal another aspect of the differential status of infested individuals within host populations.

In conclusion, our results support the hypothesis that parasitism is a major determining factor in gonad plasticity in males in mammals. The relative importances of the effects of parasites and of the adaptive plasticity of hosts in the observed pattern have to be deepened. An examination of the interaction between pathogens and the other sources or regulatory organs of the endocrine system (Soma et al., 2000) might also provide a better understanding of the functional layout of endocrine glands and of the selective pressures that drive their evolution.

\section{Acknowledgements}

We would like to thank the Consejería de Medio Ambiente de la Junta de Andalucía and in particular the Espacio 
Natural de Sierra Nevada (ENSN) for their logistic support. Special thanks are due to the park wardens and fieldworkers at the ENSN, particularly to Apolo Sánchez-Lao, José López-Pérez, Isidro Puga-González, Elías Martínez-Ortiz, Francisco Javier Pérez-Díaz, Francisco Casado-Felipe, Antonio José Rodríguez-Dueñas and Antonio Rodríguez Huete for their professional and personal involvement in the study area. Thank-you also to Michael Lockwood and Agnès Sarasa for the English revision. A.J. Mark Hewison, (INRACEFS, France) provided valuable suggestions and Sylvain Losdat (University of Berne, Switzerland), Cédric GirardButtoz (German Primate Centre, Germany) made valuable comments on an earlier draft of this manuscript. MS was supported by a MENRT grant (France) and ES by the Juan de la Cierva program (MICINN, Spain). The research activities of JEG, RCS, and JMP are also partially supported by the Plan Andaluz de Investigación Desarrollo e Innovación de la Junta de Andalucía (RNM-118). This study complied with the current laws of the country in which it was performed.

\section{References}

Alasaad, S., Soglia, D., Sarasa, M., Soriguer, R.C., Pérez, J.M., Granados, J.E., Rasero, R., Zhu, X.Q., Rossi, L., 2008. Skin-scale genetic structure of Sarcoptes scabiei populations from individual hosts: empirical evidence from Iberian ibex-derived mites. Parasitol. Res. 104, 101-105.

Anderson, D.R., Burnham, K.P., Thompson, W.L., 2000. Null hypothesis testing: problems, prevalence, and an alternative. J. Wildl. Manage. 64, 912-923.

Anderson, D.R., Link, W.A., Johnson, D.H., Burnham, K.P., 2001. Suggestions for presenting the results of data analyses. J. Wildl. Manage. 65, 373-378.

Arlian, L.G., Bruner, R.H., Stuhlman, R.A., Ahmed, M., Vyszenskimoher, D.L., 1990. Histopathology in hosts parasitized by Sarcoptes scabiei. J. Parasitol. 76, 889-894.

Awata, S., Heg, D., Munehara, H., Kohda, M., 2006. Testis size depends on social status and the presence of male helpers in the cooperatively breeding cichlid Julidochromis ornatus. Behav. Ecol. 17, 372-379.

Balestrieri, A., Remonti, L., Ferrari, N., Ferrari, A., Lo Valvo, T., Robetto, S., Orusa, R., 2006. Sarcoptic mange in wild carnivores and its cooccurrence with parasitic helminths in the Western Italian Alps. Eur. J. Wildl. Res. 52, 196-201.

Barnard, C.J., Behnke, J.M., 1990. Parasitism and Host Behaviour. Taylor and Francis, London, 332 pp.

Baudoin, M., 1975. Host castration as a parasitic strategy. Evolution 29, 335-352.

Beehner, J.C., Bergman, T.J., Cheney, D.L., Seyfarth, R.M., Whitten, P.L., 2006. Testosterone predicts future dominance rank and mating activity among male chacma baboons. Behav. Ecol. Sociobiol. 59, 469479.

Bergman, T.J., Beehner, J.C., Cheney, D.L., Seyfarth, R.M., Whitten, P.L., 2006. Interactions in male baboons: the importance of both males' testosterone. Behav. Ecol. Sociobiol. 59, 480-489.

Bize, P., Roulin, A., Tella, J.L., Bersier, L.F., Richner, H., 2004. Additive effects of ectoparasites over reproductive attempts in the long-lived alpine swift. J. Anim. Ecol. 73, 1080-1088.

Bowman, A.W., Azzalini, A., 1997. Applied Smoothing Techniques for Data Analysis: The Kernel Approach with S-Plus Illustrations. Oxford University Press, Oxford, 208 pp.

Burnham, K.P., Anderson, D.R., 2002. Model Selection and Multimodel Inference: A Practical Information-Theoric Approach. Springer, New York, 488 pp.

Camkerten, I., Sahin, T., Borazan, G., Gokcen, A., Erel, O., Das, A., 2009. Evaluation of blood oxidant/antioxidant balance in dogs with sarcoptic mange. Vet. Parasitol. 154, 98-102.

Coltman, D.W., Festa-Bianchet, M., Jorgenson, J.T., Strobeck, C., 2002. Agedependent sexual selection in bighorn rams. Proc. R. Soc. B 269, 165-172.

Combes, C., 1995. Intéractions durables: écologie et évolution du parasitisme. Masson, Paris, 524 pp.

Consejería de Medio Ambiente - Junta de Andalucía, 2002. Sierra Nevada: datos basicos. Grupo Entorno, Granada, 16 pp.
Cramer, M.J., Cameron, G.N., 2007. Effects of bot fly, Cuterebra fontinella, parasitism on male aggression and female choice in Peromyscus leucopus. Anim. Behav. 74, 1419-1427.

Davidson, R.K., Bornstein, S., Handeland, K., 2008. Long-term study of Sarcoptes scabiei infection in Norwegian red foxes (Vulpes vulpes) indicating host/parasite adaptation. Vet. Parasitol. 156, 277-283.

Dimri, U., Sharma, M.C., Swarup, D., Ranjan, R., Kataria, M., 2008. Alterations in hepatic lipid peroxides and antioxidant profile in Indian water buffaloes suffering from sarcoptic mange. Res. Vet. Sci. 85, 101-105.

Elder, B.L., Arlian, L.G., Morgan, M.S., 2009. Modulation of human dermal microvascular endothelial cells by Sarcoptes scabiei in combination with proinflammatory cytokines, histamine, and lipid-derived biologic mediators. Cytokine 47, 103-111.

Fandos, P., 1991. La cabra montés (Capra pyrenaica) en el Parque Natural de las Sierras de Cazorla Segura y las Villas. ICONA-CSIC, Madrid, 176 pp.

Fischer, K., Bergstrom, F., Reynolds, S., Willis, C., Johnstone, M., Mika, A., Langendorf, C., Buckle, A.M., Pike, R.N., Blom, A.M., Kemp, D.J., 2009. Complement evasion of the scabies mite Sarcoptes scabiei. In: 12th European Meeting on Complement in Human Disease, Visegrad, Hungary, Sep 05-08, p. 2849.

Forbes, M.R.L., 1993. Parasitism and host reproductive effort. Oikos 67, 444-450.

Garthwaite, S.M., Cheng, H., Bryan, J.E., Craig, B.W., Holloszy, J.O., 1986. Aging, exercise and food restriction: effects on body composition. Mech. Ageing Dev. 36, 187-196.

Goeritz, F., Quest, M., Wagener, A., Fassbender, M., Broich, A., Hildebrandt, T.B., Hofmann, R.R., Blottner, S., 2003. Seasonal timing of sperm production in roe deer: interrelationship among changes in ejaculate parameters, morphology and function of testis and accessory glands. Theriogenology 59, 1487-1502.

Gulland, F.M.D., 1995. The impact of infectious diseases on wild animal populations: a review. In: Grenfell, B.T., Dobson, A.P. (Eds.), Ecology of Infectious Diseases in Natural Populations. Cambridge University Press, Cambridge, pp. 20-51.

Harcourt, A.H., Harvey, P.H., Larson, S.G., Short, R.V., 1981. Testis weight, body-weight and breeding system in primates. Nature 293, 55-57.

Harper, E.J., 1998. Changing perspectives on aging and energy requirements: aging, body weight and body composition in humans, dogs and cats. J. Nutr. 128, 2627S-2631S.

Hart, B.L., 1988. Biological basis of the behavior of sick animals. Neurosci. Biobehav. Rev. 12, 123-137.

Heath, A.C.G., 1978. Scrotal mange mite, Chorioptes bovis (Hering, 1845) on sheep: seasonality, pathogenicity and intra-flock transfer. N. Z. Vet. J. 26, 299-300.

Hudson, P.J., Dobson, A.P., 1997. Host-parasite processes and demographic consequences. In: Clayton, D.H., Moore, J.M. (Eds.), Host-parasite Evolution: General Principles and Avian Models. Oxford University Press, Oxford, pp. 128-154.

Hughes, D.P., Kathirithamby, J., Turillazzi, S., Beani, L., 2004. Social wasps desert the colony and aggregate outside if parasitized: parasite manipulation? Behav. Ecol. 15, 1037-1043.

Hughes, V.A., Frontera, W.R., Roubenoff, R., Evans, W.J., Singh, M.A.F., 2002. Longitudinal changes in body composition in older men and women: role of body weight change and physical activity. Am. J. Clin. Nutr. 76, 473-481.

Hurd, H., 2001. Host fecundity reduction: a strategy for damage limitation? Trends Parasitol. 17, 363-368.

Hurtrez-Boussès, S., Blondel, J., Perret, P., Fabreguettes, J., Renaud, F., 1998. Chick parasitism by blowflies affects feeding rates in a Mediterranean population of blue tits. Ecol. Lett. 1, 17-20.

Iason, G.R., Boag, B., 1988. Do intestinal helminths affect condition and fecundity of adult mountain hares. Wildl. Dis. 24, 599-605.

Kolluru, G.R., Grether, G.F., Dunlop, E., South, S.H., 2009. Food availability and parasite infection influence mating tactics in guppies (Poecilia reticulata). Behav. Ecol. 20, 131-137.

Kuhn, C., Lucius, R., Matthes, H.F., Meusel, G., Reich, B., Kalinna, B.H., 2008. Characterisation of recombinant immunoreactive antigens of the scab mite Sarcoptes scabiei. Vet. Parasitol. 153, 329-337.

Kyle, U.G., Genton, L., Hans, D., Karsegard, V.L., Michel, J.-P., Slosman, D.O., Pichard, C., 2001. Total body mass, fat mass, fat-free mass, and skeletal muscle in older people: cross-sectional differences in 60-year-old persons. J. Am. Geriat. Soc. 49, 1633-1640.

Lafferty, K.D., Kuris, A.M., 2009. Parasitic castration: the evolution and ecology of body snatchers. Trends Parasitol. 25, 564-572.

León-Vizcaíno, L., Ruiz de Ybañez, M.R., Cubero, M.J., Ortiz, J.M., Espinosa, J., Pérez, L., Simón, M.A., Alonso, F., 1999. Sarcoptic mange in Spanish ibex from Spain. J. Wildl. Dis. 35, 647-659. 
Lincoln, G.A., 1998. Reproductive seasonality and maturation throughout the complete life-cycle in the mouflon ram (Ovis musimon). Anim. Reprod. Sci. 53, 87-105.

Little, S.E., Davidson, W.R., Rakich, P.M., Nixon, T.L., Bounous, D.I., Nettles, V.F., 1998. Responses of red foxes to first and second infection with Sarcoptes scabiei. J. Wildl. Dis. 34, 600-611.

Marzal, A., de Lope, F., Navarro, C., Moller, A.P., 2005. Malarial parasites decrease reproductive success: an experimental study in a passerine bird. Oecologia 142, 541-545.

McCallum, H., Barlow, N., Hone, J., 2001. How should pathogen transmission be modelled. Trends Ecol. Evol. 16, 295-300.

Miller, M.W., Williams, E.S., 2003. Horizontal prion transmission in mule deer. Nature 425, 35-36.

Møller, A.P., 1997. Parasitism and the evolution of host life history. In: Clayton, D.H., Moore, J.M. (Eds.), Host-parasite Evolution: General Principles and Avian Models. Oxford University Press, Oxford, pp. 105-127.

Moore, J., Gotelli, N.J., 1990. Phylogenetic perspective on the evolution of altered host behaviour: a critical look at the manipulation hypothesis. In: Barnard, C.J., Behnke, J.M. (Eds.), Parasitism and Host Behaviour. Taylor and Francis, London, pp. 193-229.

Nakagawa, T., Takai, Y., Kubo, M., Sakai, H., Masegi, T., Yanai, T., 2009. A pathological study of sepsis associated with sarcoptic mange in raccoon dogs (Nyctereutes procyonoides) in Japan. J. Comp. Pathol. 141, 177-181.

Neuhaus, P., 2003. Parasite removal and its impact on litter size and body condition in Columbian ground squirrels (Spermophilus columbianus). Proc. R. Soc. B 270, S213-S215.

Newey, S., Thirgood, S., 2004. Parasite-mediated reduction in fecundity of mountain hares. Proc. R. Soc. B 271, S413-S415.

Newey, S., Thirgood, S.J., Hudson, P.J., 2004. Do parasite burdens in spring influence condition and fecundity of female mountain hares Lepus timidus? Wildl. Biol. 10, 171-176.

Obrebski, S., 1975. Parasite reproductive strategy and evolution of castration of hosts by parasites. Science 188, 1314-1316.

O'Donnell, S., 1997. How parasites can promote the expression of social behaviour in their hosts. Proc. R. Soc. B 264, 689-694.

Pélabon, C., Borg, A.A., Bjelvenmark, J., Barber, I., Forsgren, E., Amundsen, T., 2005. Do microsporidian parasites affect courtship in two-spotted gobies? Mar. Biol. 148, 189-196.

Pelletier, F., Hogg, J.T., Festa-Bianchet, M., 2004. Effect of chemical immobilization on social status of bighorn rams. Anim. Behav. 67, 1163-1165.

Pence, D.B., Ueckermann, E., 2002. Sarcoptic manage in wildlife. Rev. sci. tech. Off. int. Epiz. 21, 385-398.

Pence, D.B., Windberg, L.A., 1994. Impact of a sarcoptic mange epizootic on a coyote population. J. Wildl. Manage. 58, 624-633.

Pérez, J.M., Gonzalez, F.J., Serrano, E., Granados, J.E., Fandos, P., Carro, F., Soriguer, R.C., 2006. Is blood collected from shot Iberian ibex (Capra pyrenaica) useful for monitoring their physiological status? Eur. J. Wildl. Res. 52, 125-131.

Pérez, J.M., Granados, J.E., Soriguer, R.C., Fandos, P., Marquez, F.J., Crampe, J.P., 2002. Distribution, status and conservation problems of the Spanish Ibex, Capra pyrenaica (Mammalia:Artiodactyla). Mammal Rev. 32, 26-39.

Pérez, J.M., Ruiz-Martínez, I., Granados, J.E., Soriguer, R.C., Fandos, P., 1997. The dynamics of sarcoptic mange in the ibex population of Sierra Nevada in Spain - influence of climatic factors. J. Wildl. Res. 2, 86-89.

Pérez, J.M., Granados, J.E., Soriguer, R.C., 1994. Population dynamic of the Spanish ibex Capra pyrenaica in sierra Nevada natural park (southern Spain). Acta Theriol. 39, 289-294.

Perrin, N., Christe, P., Richner, H., 1996. On host life-history response to parasitism. Oikos 75, 317-320.

Pioz, M., Loison, A., Gibert, P., Jullien, J.M., Artois, M., Gilot-Fromont, E., 2008. Antibodies against Salmonella is associated with reduced reproductive success in female alpine chamois (Rupicapra rupicapra). Can. J. Zool. 86, 1111-1120.

Preston, B.T., Stevenson, I.R., Pemberton, J.M., Coltman, D.W., Wilson, K., 2003. Overt and covert competition in a promiscuous mammal: the importance of weaponry and testes size to male reproductive success. Proc. R. Soc. B 270, 633-640.

R Development Core Team 2009. R: A Language and Environment for Statistical Computing. (Vienna, R Foundation for Statistical Computing), http://www.r-project.org.

Rhodes, A.P., 1975. Seminal degeneration associated with chorioptic mange of scrotum of rams. Aust. Vet. J. 51, 428-432.

Rhodes, A.P., 1976. Effect of extensive chorioptic mange of scrotum on reproductive function of ram. Aust. Vet. J. 52, 250-257.
Ruiz-Martínez, I., Soler-Cruz, M.D., Pérez-Jiménez, J.M., Díaz-López, M., 1993. Miasis genitales por Wohlfahrtia magnifica (Schiner, 1862) (Diptera, Sarcophagidae): ¿Una hipótesis sobre la teoría de la castración del hospedador? Bol. R. Soc. Esp. Hist. Nat. (Sec. Biol.) 89, 51-61.

Santiago-Moreno, J., Luzón, M., Coloma, M.A., Pulido-Pastor, A., GómezGuillamón, F., de la Vega,F R.S., Toledano-Díaz, A., López-Sebastián, A, 2010. Relationship between Iberian ibex (Capra pyrenaica) sperm quality and level of parasitism. Eur. J. Wildl. Res. 56, 605611.

Sarasa, M., Rambozzi, L., Rossi, L., Meneguz, P.G., Serrano, E., Granados, J.E., González, F.J., Fandos, P., Soriguer, R.C., Gonzalez, G., Joachim, J., Pérez, J.M., 2010a. Sarcoptes scabiei: specific immune response to sarcoptic mange in the Iberian ibex Capra pyrenaica depends on previous exposure and sex. Exp. Parasitol. 124, 265-271.

Sarasa, M., Serrano, E., Pérez, J.M., Soriguer, R.C., Gonzalez, G., Joachim, J., Fandos, P., Granados, J.E., 2010b. Effects of season, age, and body condition on allocation to testes mass in Iberian ibex. J. Zool. 281, $125-131$.

Sarasa, M., Serrano, E., Gonzalez, G., Granados, J.E., Soriguer, R.C., Pérez, J.M., Joachim, J., 2009. Pseudoectoparasites: a new tool for exploring the relationship between host behaviour and ectoparasites. Anim. Behav. 77, 1351-1356.

Schärer, L., Ladurner, P., Rieger, R.M., 2004. Bigger testes do work more: experimental evidence that testis size reflects testicular cell proliferation activity in the marine invertebrate, the free-living flatworm Macrostomum sp. Behav. Ecol. Sociobiol. 56, 420-425.

Schärer, L., Vizoso, D.B., 2007. Phenotypic plasticity in sperm production rate: there's more to it than testis size. Evol. Ecol. 21, 295-306.

Schulte-Hostedde, A.I., Millar, J.S., 2004. Intraspecific variation of testis size and sperm length in the yellow-pine chipmunk (Tamias amoenus): implications for sperm competition and reproductive success. Behav. Ecol. Sociobiol. 55, 272-277.

Schulte-Hostedde, A.I., Millar, J.S., Hickling, G.J., 2005a. Condition dependence of testis size in small mammals. Evol. Ecol. Res. 7, 143-149.

Schulte-Hostedde, A.I., Zinner, B., Millar, J.S., Hickling, G.J., 2005b. Restitution of mass-size residuals: validating body condition indices. Ecology 86, 155-163.

Serrano, E., Granados, J.E., Pérez, J.M., 2007. Sarcoptic mange and metapodial development in growing male Iberian ibex (Capra pyrenaica). Vet. Parasitol. 144, 375-379.

Serrano, E., Granados, J.E., Sarasa, M., González, F.J., Fandos, P., Soriguer, R.C., Pérez, J.M., in press. The effects of winter severity and population density on body stores in the Iberian wild goat (Capra pyrenaica) in a highly seasonal mountain environment. Eur. J. Wildl. Res., doi:10.1007/s10344-010-0398-5.

Skerratt, L.F., 2003. Clinical response of captive common wombats (Vombatus ursinus) infected with Sarcoptes scabiei var. wombati. J. Wildl. Dis. 39, 179-192.

Skerratt, L.F., Middleton, D., Beveridge, L., 1999. Distribution of life cycle stages of Sarcoptes scabiei var wombati and effects of severe mange on common wombats in Victoria. J. Wildl. Dis. 35, 633-646.

Soma, K.K., Tramontin, A.D., Wingfield, J.C., 2000. Oestrogen regulates male aggression in the non-breeding season. Proc. R. Soc. B 267, 1089-1096.

Soulsbury, C.D., Iossa, G., Baker, P.J., Cole, N.C., Funk, S.M., Harris, S., 2007. The impact of sarcoptic mange Sarcoptes scabiei on the British fox Vulpes vulpes population. Mammal Rev. 37, 278-296.

Toledano-Díaz, A., Santiago-Moreno, J., Gómez-Brunet, A., Pulido-Pastor, A., López-Sebastián, A., 2007. Horn growth related to testosterone secretion in two wild Mediterranean ruminant species: the Spanish ibex (Capra pyrenaica hispanica) and European mouflon (Ovis orientalis musimon). Anim. Reprod. Sci. 102, 300-307.

Velando, A., Drummond, H., Torres, R., 2006. Senescent birds redouble reproductive effort when ill: confirmation of the terminal investment hypothesis. Proc. R. Soc. B 273, 1443-1448.

Virgin Jr., C.E., Sapolsky, R.M., 1997. Styles of male social behavior and their endocrine correlates among low-ranking baboons. Am. J. Primatol. 42, 25-39.

Whittingham, M.J., Stephens, P.A., Bradbury, R.B., Freckleton, R.P., 2006. Why do we still use stepwise modelling in ecology and behaviour? J. Anim. Ecol. 75, 1182-1189.

Wood, S.N., 2006. Generalized Additive Models, an Introduction with R. Chapman \& Hall/CRC, Boca Raton, 392 pp.

Wright, S., 1931. Evolution in mendelian populations. Genetics 16, 97-159.

Wright, S., 1938. Size of population and breeding structure in relation to evolution. Science 87, 430-431.

Zuur, A.F., Ieno, E.N., Smith, G.M., 2007. Analysing Ecological Data. Springer, New York, 672 pp. 